\author{
ks. Jacek Kempa
}

\title{
Maryjność wobec tajemnicy odkupienia
}

Zaproponowany tytuł może niepokoić pewną nieostrością sformułowania. Intuicyjnie rzecz ujmując, terminowi „maryjność” zapewne najbliżej jest do określenia „pobożność maryjna”. Ale w niniejszej refleksji ma on objąć nieco inny obszar: nie tyle bezpośrednio przeżywanej pobożności maryjnej, ile teologicznego namysłu nad tym, jak jest ona przeżywana. Przy tym nie chodzi tu tylko o akcentowanie kultu czy treści związanych wprost z Maryją, ale też o pewien rodzaj wrażliwości na wiarę i jej treści, którą wywołuje rozbudzona pobożność maryjna. Stąd w niniejszej refleksji termin „maryjność” będzie wymienny z wyrażeniem „wrażliwość maryjna”. Dzięki temu powinno być też jasne, że nie chodzi o izolowanie tego, co "maryjne”, od całego dziedzictwa wiary i budowanie samodzielnego obszaru wiary i refleksji nad nią. To byłoby niebezpieczne dla jedności wiary, jak już wielokrotnie wskazywano w badaniach nad historią mariologii ${ }^{1}$. „Maryjność" odnosi się raczej do całości wiary i spojrzenia na nią z wrażliwością zdobywaną w rozważaniu tajemnic Matki Bożej. W nieunikniony sposób pojawia się w takiej przestrzeni dwukierunkowość oddziaływań: tak opisana maryjność podpowiada pewien specyficzny sposób przeżywania wiary i rozumienia jej treści, a równocześnie wiara w swej całości rzutuje na przeżywa-

1 Por. G. Colzani, Wspótczesna mariologia. Weryfikacja teologiczna, „Salvatoris Mater" 3 (2002), s. 255-269. 
nie i rozumienie treści mariologicznych i postaw inspirowanych maryjną pobożnością.

Warto prześledzić tak zarysowane zakresy zależności w obszarze zawężonym, aczkolwiek oferującym wciąż wyraźne odniesienia do różnych treści teologicznych. Takim obszarem jest niewątpliwie teologia odkupienia. Jest to dziedzina teologiczna jednoznacznie zbudowana na tajemnicach Trójcy i wcielenia, a jednocześnie wewnętrznie nieokrzepła w poszukiwaniu racjonalnych przybliżeń do Bożej logiki odkupienia. Charakteryzuje ją także ciągłe wychodzenie ku rozmaitym - w zasadzie wszystkim - obszarom teologii, by podtrzymywać ich spojenie z centrum wiary, jakim jest zbawienie w Chrystusie (np. Kościół rozumiejący siebie przez pryzmat służby zbawieniu czy rzeczy ostateczne pojmowane jako pełnia zbawienia, a nie pseudoracjonalny system „fizyki rzeczy ostatecznych”).

Zatem w miejscu spotkania obu zarysowanych właśnie obszarów powstaje następujący problem: czy wrażliwość maryjna teologa, a szerzej: każdego wierzącego, rzutuje jakoś na konkretne rozłożenie akcentów w teologii odkupienia? Zarazem trzeba rozpatrzeć problem odwrotnego oddziaływania: jakie znaczenie ma dla wrażliwości maryjnej teologia odkupienia, zwłaszcza jej charakterystyczna wielowątkowość?

Tak zadane pytanie o relację między „maryjnością” a teologią odkupienia wymaga jeszcze jednego wstępnego wyjaśnienia. Nawiązanie do spotkania tych dwu obszarów przywołuje skojarzenia z próbami określenia aktywnego udziału Maryi w odkupieniu dokonanym przez Chrystusa, co kumuluje się w dyskusjach nad kwestią tytułu „Współodkupicielka”. Trzeba więc na początek jasno zadeklarować, że refleksja tu prowadzona będzie wyrastała z mariologii eklezjotypicznej, charakterystycznej dla soborowego zwrotu w tej dziedzinie. Chodzi nam zatem o Maryję przyjmującą dar odkupienia. Jeśli natomiast wchodzi w grę jakiś rodzaj mowy o uczestnictwie w przekazywaniu daru zbawienia, to zawsze w takim sensie, jaki jest właściwy całemu Kościołowi 
i każdemu jego członkowi - nawet gdy w odniesieniu do Maryi zostanie podkreślone Jej pierwszeństwo, Jej doskonałość w takim działaniu.

Niniejszą refleksję należy rozumieć jako zaproszenie do dyskusji, nie zaś jako efekt pracy analitycznej. Treści tu prezentowane należą do problematyki powszechnie znanej. Dlatego $\mathrm{w}$ dużej mierze rezygnuję z przytaczania literatury przedmiotu. Ta bowiem niemal w każdym z przywoływanych zakresów jest niezwykle obszerna i powszechnie znana, często na poziomie podręcznikowym. Główny mój zamiar polega na zasugerowaniu pewnych, w dużej części z pewnością nienowych, mariologicznie ugruntowanych zagadnień, które mogą okazać się inspirujące w zetknięciu z teologią odkupienia.

Możliwości ułożenia tematów w tak zadeklarowanym polu problemowym jest wiele. Żeby jakoś uporządkować tę refleksję, podejmę próbę odniesienia do czterech dogmatów maryjnych, by w ich obrębie przedyskutować zadeklarowane relacje między maryjnością a teologią odkupienia.

\section{Boża Rodzicielka}

Znany jest kontekst ogłoszenia tytułu „Boża Rodzicielka”. To efeskie określenie odnoszące się do Maryi pomaga nie tylko w nazwaniu prawdziwego bóstwa i człowieczeństwa Chrystusa, ale też $\mathrm{w}$ próbie określenia relacji między oboma naturami w Chrystusie. Zastosowana tu idea wymiany orzekań nabierze w Chalcedonie ram formalnego określenia "niezmieszane - nierozdzielone". Intuicja pozostaje ta sama. W Efezie jednak to tytuł Maryi będzie musiał wystarczyć.

Tytuł Theotokos stanowi zatem - jako fundament chrystologii ontologicznej - niezwykle ważny punkt odniesienia dla teologii odkupienia. Przypomina bowiem, że jedyne pośrednictwo zbawcze Chrystusa wynika z Jego bosko-ludzkiej tożsamości i na niej 
się opiera. Stąd zaś prosta droga prowadzi do przypomnienia, że warunkiem poprawnego rozumienia dzieła zbawienia jest uznanie takiej właśnie tożsamości Chrystusa i właściwe zinterpretowanie boskiego i ludzkiego działania i woli w tym procesie.

Podobnie jak późniejszy dogmat ogłoszony w Chalcedonie opisuje kwestię tożsamości Chrystusa przez odrzucenie skrajnych rozwiązań, tak też łatwiej jest określić granice poprawności teologii odkupienia niż jej centrum, gdzie jest miejsce na wiele różnych koncepcji. Zatem także w teologii odkupienia można zdiagnozować nestoriańską i monofizycką tendencję. Ta pierwsza traci z oczu wartość Bożego działania Jezusa człowieka. Manifestuje się w ujęciach soteriologii, w których Jezus jest widziany jedynie jako prorok, nauczyciel, który otrzymał misję od Boga. W misję tę zaangażowana jest jednostronnie ludzka natura Chrystusa, a niejasna pozostaje kwestia zaangażowania Boga w Chrystusie. Skuteczność tak szkicowanego działania zbawczego jest ograniczona. Zwykle problem polega na tym, że pozostaje ona apelem do ludzi. W ten sposób nestoriańskie zaburzenie jedności natur prowadzi łatwo do pelagiańskiego zniekształcenia zbawienia, które zatrzymuje się na apelowaniu do moralności ludzi. Nie jest to jedyny możliwy błąd wynikający z braku podkreślenia jedności działania boskiego i ludzkiego w Chrystusie, ale błąd najbardziej charakterystyczny.

Z kolei tendencja monofizycka prowadzi do zniekształcenia w soteriologii, które lekceważy autonomiczność ludzkiego działania w Chrystusie. W efekcie więc przede wszystkim uniemożliwia ona najważniejsze teorie odkupienia wypracowane w okresie średniowiecza. Tym, co je bowiem wiąże, jest podkreślenie wartości i potrzeby ludzkiego działania Chrystusa, nieumniejszonego w żaden sposób przez bóstwo, ale wyniesionego przez nie na nowy poziom godności. By pozostać przy klasycznych przykładach: według Anzelma koniecznie ludzkie zadośćuczynienie Chrystusa zyskuje dzięki zjednoczeniu z Bogiem wartość nieskończoną, a więc więcej niż wystarczającą do uratowania całej 
ludzkości ${ }^{2}$. Według Tomasza zaś ten sam „mechanizm” zostaje powiązany także ze zdobywaną przez Jezusa zasługą ${ }^{3}$.

Zatem tytuł Theotokos postrzegany we właściwym, czyli pierwotnym, kontekście pomaga zachować wrażliwość na zachowanie poprawnych ram refleksji soteriologicznej - podobnie jak czyni to wobec samej chrystologii ontologicznej. Natomiast warto zauważyć, że istnieje także niebezpieczeństwo, które wynika z niewłaściwego odczytania tegoż tytułu. Otóż tytuł Theotokos odseparowany od chrystologicznego kontekstu jego powstania może bez trudu przewartościować myślenie o Maryi, pozwalając nawet na mitologiczne traktowanie nadające Jej cechy boskie. W oczywisty sposób ma to katastrofalne konsekwencje w całej wierze, a więc także $\mathrm{w}$ pojmowaniu odkupienia zapośredniczonego jedynie przez Chrystusa, Boga-człowieka.

\section{Zawsze Dziewica}

Ten tytuł maryjny, przyjęty jako dogmat nie przez formalne ogłoszenie, ale na podstawie powszechności i dawności nauczania, również wyraźnie odsłania pewną „wrażliwość maryjną”, która ma znaczenie w szeroko uprawianej teologii. Potrzebne jest w każdym razie najpierw dotarcie do właściwego sensu formuły o dziewictwie Maryi ante partem, in partu i post partem. Sens ten nie jest zupełnie oczywisty, czego świadectwem są toczone dyskusje, a w nowożytności także głosy nawołujące do czysto symbolicznego rozumienia ${ }^{4}$. Warto docenić koncepcję,

2 Por. Cur Deus homo, Ks. 2, rozdz. 6.

3 Por. Summa Theologiae, pars III, q. 48, a. 1. Por. M. Paluch, Dlaczego Tomasz, Warszawa 2012, s. 173-178, 183-186.

4 Znakomite i aktualne omówienie historii debat w tym zakresie zob. G. Greshake, Maria - Ecclesia. Perspektiven einer marianisch grundierten Theologie und Kirchenpraxis, Regensburg 2014. W dalszym przedstawieniu zagadnienia opieram się na tej pracy. 
która mówi, że nie chodzi jedynie ani nawet pierwszorzędnie o kwestię tzw. integralności cielesnej. Ta bowiem jest kłopotliwa $\mathrm{w}$ odniesieniu do dziewictwa in partu i post partem, jeśli chce się poważnie potraktować podejrzenia o doketyzm. W dodatku koncentracja na cielesności w pojmowaniu dziewictwa prowadzi do poważnych problemów z uzasadnieniem w perspektywie eschatologicznej równości życia bezżennego i życia małżeńskiego, a więc wykrzywia w stronę manicheizmu perspektywę chrześcijańskiego myślenia o płciowości i prokreacji. Problem rozwiązuje się w dużym stopniu, gdy dziewictwo Maryi rozumie się w najpierw w kontekście chrystologicznym, a następnie duchowym. Kontekst chrystologiczny podpowiada, że przyjście na świat Boga Wcielonego jest zupełną nowością, efektem Bożej interwencji, która nie ma analogii w dziejach świata poza jedną, jaką jest sam akt stworzenia. Bóg swoją stwórczą mocą stwarza więc w łonie Maryi człowieka, który w swoim jednostkowym ludzkim istnieniu jest od początku Logosem Wcielonym, czyli swoje jednostkowe ludzkie istnienie zawdzięcza temu, że to Logos formuje jego tożsamość. Świadomość, że chodzi tu o początek tajemnicy wcielenia, każe odrzucić mitologiczne skojarzenia o tym, że Bóg zastępuje pierwiastek męski w poczęciu w łonie Maryi. Za tą prawdą o chrystologicznym charakterze idzie zrozumienie duchowego sensu dziewictwa Maryi. Jest Ona więc osobą zupełnie Bogu oddaną, pozwalającą Mu działać w Niej w sposób Jemu właściwy, a więc stwórczy. Jest oddana Bogu przez wiarę, nadzieję i miłość. Ojcowie Kościoła łatwo odnajdą w tym rozumieniu dziewiczości Maryi wzór dla Kościoła. W ten sposób zostaje usunięta na drugi plan kwestia fizycznej dziewiczości, choć ta będzie nadal znakiem dla wymienionych duchowych wymiarów: chrystologicznego i eklezjologicznego 5 .

Synonimem dziewiczości staje się $\mathrm{w}$ takim rozumieniu wyznanie Maryi ze zwiastowania: „niech mi się stanie według słowa

5 Por. tamże, s. 233-235. 
Twego". Tradycja chrześcijańska nauczyła się czytać te słowa w ten sposób, że widzi w nich stałą dyspozycję Maryi, a nie taką, która byłaby ograniczona do chwili zwiastowania. W tym sensie pojawia się tu myśl o Maryi „zawsze Dziewicy”.

Do powiązań z teologią odkupienia prowadzi stwierdzenie, że tak opisana postawa Maryi jest stałym punktem odniesienia dla duchowości chrześcijańskiej. Dlaczego jest taka ważna? W niej wyraża się - moim zdaniem - kilka bardziej szczegółowych postaw, które warto wymienić i zobaczyć, jak ogniskują się w problematyce dotyczącej odkupienia. Najpierw: niczym nieograniczona otwartość na Boga (czyli Jego wolę) zakłada pokorę. Pokora opisuje postawę człowieka pozostającego w jakiejś relacji. Wyrasta z przyjęcia prawdy o tej relacji. Człowiek odnoszący się do Boga ma możliwość uznania prawdy o swojej zupełnej zależności od Niego. Może także w prawdzie uznać swoją moralną słabość, która rzutuje na jego relację z Bogiem. W ten sposób staje się pokorny przed Bogiem.

Przykład Maryi pokazuje, że pokora prowadzi dalej do rozumnego posłuszeństwa. Dodaję określenie „rozumne”, bo jego ślad znajduje się w scenie zwiastowania: w rozmowie, jaką Maryja podejmuje, zgadzając się na wolę Boga. To drobne określenie ma istotne znaczenie: posłuszeństwo wobec Boga, wynikające $\mathrm{z}$ rozpoznania własnej kondycji przed Nim jako nieskończonym majestatem, w żaden sposób nie wymazuje wagi odpowiedzialności człowieka za jego wolne wybory. Więcej: posłuszeństwo wobec Boga zakłada pełną akceptację osobową, a więc wolną decyzję osoby. Takie przekonanie wynika z obserwacji tajemnicy Maryi ze sceny zwiastowania, jaką przez wieki rozwijała chrześcijańska tradycja. To ważne przekonanie, obecne już w starożytnym Kościele, trzeba szczególnie uważnie podkreślać w kontekście nowożytnej debaty nad możliwością wolności człowieka wiążącego się z Bogiem przez wiarę.

Wreszcie: pokora wyrastająca ze spotkania z Bogiem, a także posłuszeństwo wobec Niego prowadzą do nadziei. Ta perspekty- 
wa otwiera się w zrozumiały sposób w życiu Maryi: po zwiastowaniu, czyli po momencie decydującego powierzenia siebie woli Boga, przychodzi czas na radosne wyznanie nadziei w Magnificat. O czym to świadczy? Pokora (jako wyraz uznania prawdy o sobie przed Bogiem) i posłuszeństwo (jako respektujący prawdę akt wolności przed Bogiem) są aktami najgłębiej ludzkimi, nie zaś ograniczającymi człowieka. Dlatego wobec Boga nie tylko możliwa, ale zupełnie racjonalna jest nadzieja, która nie może być pomyślana inaczej jak tylko w powiązaniu z realizacją człowieczeństwa, a w niej z realizacją wolności.

Pozostańmy przy takim rozpisaniu postawy duchowej znamionującej dziewictwo Maryi: otwartość na Boga, to znaczy na Jego wolę, jako pokora, posłuszeństwo i nadzieja wobec Niego. Jakie znaczenie mają te treści dla teologii odkupienia?

Teologia odkupienia znalazła się w okresie nowożytnym w ogniu krytyki przychodzącym pozornie z wielu stron. Można jednak wskazać, że zasadnicze przesłanie tej krytyki zostało szczególnie wyraźnie sformułowane już przez Immanuela Kanta: człowiek dojrzały jest nieodwołalnie odpowiedzialny za swoje decyzje, wina jest nieprzekazywalna ${ }^{6}$. Stąd wiara w odkupienie dokonane zastępczo przez Chrystusa wygląda na niemożliwą do pogodzenia z ideą wolności ujmowanej jako autonomia podmiotu. Odtąd możliwy był rozwój podejrzeń, że chrześcijaństwo jest przeciwnikiem dążeń do realizowania autonomii podmiotu, gdy głosi niezbędność odkupienia przychodzącego od Boga, a niemożność samozbawienia lub też niemożność samodzielnej realizacji siebie w wolności. Podobne podejrzenie budzi teza o radykalnej potrzebie zbawienia wskutek zanurzenia w stan winy. Człowiek nowożytny pragnie zrzucić z siebie mniemania, w których a priori ograniczana jest jego swoboda decyzji o autokreacji. Ta myśl rozwinęła się w różnych kierunkach: czy to w marksistowskiej krytyce religii ze względów społecznych i historycznej

6 I. Kant, Beantwortung der Frage: Was ist Aufklärung?, „Berlinische Monatsschrift" 12 (1784). 
konieczności, czy nietzscheańskich zmaganiach o wyzwolonego człowieka, czy freudowskich poszukiwaniach prawdy o psychicznym dobrostanie.

Także we współczesnych formach myślenia, krytycznych wobec chrześcijaństwa, można odnaleźć te same tropy podkreślające konkurencję między wolnością i samorealizacją człowieka a wolnością Boga bądź (w ateistycznej interpretacji) wymaganiami płynącymi $z$ wiary w wyimaginowanego Boga. Ostatecznie bazują one na specyficznym obrazie Boga - władcy zazdrosnego o człowieka i z nim konkurującego. Zniekształcenia tego typu niekiedy przenikają do koncepcji teologicznych, zwłaszcza związanych z tajemnicą odkupienia. Dzieje się tak na przykład wówczas, gdy wtóruje się w nich krytyce teologii odkupienia przez krzyż, a nie próbuje się dostrzec, że interpretacja odkupienia przez mękę i śmierć Chrystusa tylko wtedy jest z gruntu nieprawidłowa, gdy opiera się na nieprawidłowym obrazie Boga. Owa nieprawidłowość leży w uznaniu, choćby częściowym, konkurencji między wolnością człowieka a wolnością Boga. Bóg nie strzeże zazdrośnie swojego szczęścia, lecz dzieli się nim ze stworzeniem. Nie żąda w zamian ofiar, lecz przez ofiarę z siebie umożliwia wyjście z wplątania w grzech. Nie zagraża wolności człowieka, lecz ją funduje.

We właściwym ujmowaniu tajemnicy Boga Zbawcy w Jego relacji z człowiekiem pomaga właśnie praktyczna postawa wiary Maryi. Treści, które odnaleźliśmy w duchowym sensie dziewictwa Maryi, wskazują na takie rozumienie człowieka w relacji z Bogiem, które każe pozostać wrażliwym na ewangeliczną prawdę o tym, że wolność człowieka jest umożliwiona przez Boga i że do ostatecznej pełni człowiek rozwija się dzięki trwaniu w więzi miłości z Nim. Pokora i posłuszeństwo wobec Boga - duchowe postawy pozornie sprzeczne $\mathrm{z}$ wymaganiami wolności - okazują się postawami znamionującymi doświadczenie wolności. Pozwalają one ostatecznie z nadzieją wyczekiwać pełni życia pojmowanej jako dar Boga. 


\section{Niepokalanie poczęta}

Dogmat o Niepokalanym Poczęciu kojarzony jest słusznie z ważnym momentem tzw. soteriologii subiektywnej, a więc wydzielonego obszaru refleksji nad odkupieniem, zajmującego się warunkami przyjmowania już dokonanego odkupienia (łaski Bożej). Ostatecznie chodzi więc o rozpoznanie w Maryi faktycznego i doskonałego przyjęcia przez człowieka samoudzielania się Boga. Tym samym chodzi też o dostrzeżenie od strony formalnej w tej historycznej realizacji możliwości przyjęcia przez człowieka zbawczego działania Boga. Z tej perspektywy nauka o niepokalanie poczętej spotyka się z nauką o wniebowziętej: w Maryi cieszącej się pełnią zbawienia ujawnia się ostatecznie skuteczność łaski i zarazem złożona w człowieku zdolność do jej finalnego przyjęcia. Ten wątek jednak, choć stanowi ważny moment wrażliwości maryjnej, pozostawmy na boku właśnie ze względu na jego przyporządkowanie do antropologii, względnie do soteriologii subiektywnej.

Jak wiadomo, w definicji dogmatycznej o niepokalanym poczęciu pojawia się bezpośrednie nawiązanie do problematyki odkupienia obiektywnego. Dzieje się to w słowach wyjaśnienia źródła przywileju Maryi: „na mocy przewidzianych zasług” Chrystusa. Wyjaśnienie to korzysta z dyskusji teologicznych toczonych przez długi czas, szczególnie tych związanych z pozycją Dunsa Szkota. Wiadomo, że spór o uznanie takiego wyjaśnienia dokumentował podstawową trudność z oficjalnym przyjęciem przekonania maryjnej wiary utrzymywanej w Kościele od wieków, trudność polegającą na uznaniu działania łaski odkupienia jeszcze przed wcieleniem. Ten moment powiązania wiary maryjnej z tajemnicą odkupienia jest więc od dawna znany. Dlatego można po prostu uznać, że od dawna umacnia on specyficzny moment w wierze w odkupienie, a po ogłoszeniu dogmatu czyni to z jeszcze większą mocą. Chodzi w nim o stwierdzenie, że odkupienie powiązane jest $\mathrm{z}$ określonym aktem zbawczym Chry- 
stusa. Formuła „na mocy przewidzianych zasług” potwierdza i umacnia przekonanie, że skuteczne działanie zbawcze Boga miało konkretne historyczne ulokowanie, to znaczy miało miejsce w Chrystusie. Teza to oczywista i centralna dla chrześcijańskiej wiary i centralna także dla teologii odkupienia. W tym miejscu naszej refleksji nasuwa się zatem znane twierdzenie, że poprawnie ujmowana wiara maryjna pomaga w zachowaniu centralnych prawd wiary. De facto powiązanie to w obrębie omawianego dogmatu wzięło się jednak z odwrotnego porządku rzeczy: to troska o poprawność w ujmowaniu treści wiary powstrzymywała Kościół przed oficjalną akceptacją wiary w niepokalane poczęcie Maryi. Dopiero gdy znalazł się wystarczająco silny argument pozwalający powiązać oba zagadnienia, ogłoszony został sam dogmat ${ }^{7}$.

Warto w przypadku tego dogmatu tak jednoznacznie odwołującego się do prawdy o odkupieniu zwrócić uwagę na jeszcze jedną zależność, która tym razem przebiega od teologii odkupienia do mariologii. Definicja dogmatyczna korzysta z pewnej partykularnej tradycji teologicznej. Ujmuje dzieło zbawienia, korzystając z kategorii „zasługi”. Takie określenie, nawiązujące do nauki Tomasza z Akwinu, zostało mocno zakotwiczone w teologii i kościelnym nauczaniu zwyczajnym, zwłaszcza okresu potrydenckiego, ale nie wyczerpuje przecież bogactwa treści związanych z odkupieniem w Chrystusie. Umieszczenie go

7 Ten ledwie zarysowany motyw zgodności wiary w odkupienie dokonujące się w historycznym wydarzeniu Chrystusa $\mathrm{z}$ wiarą w uprzednie działanie zbawcze Boga wobec Maryi nasuwa dalsze, bardziej złożone pytania, dotyczące tego, jak dalece należy rozróżniać między czasem „przed” i „po” Chrystusie, gdy bierze się pod uwagę skuteczność Bożego działania zbawczego. Czy Maryja jest wyjątkiem, czy też przywilej „uprzedniego odkupienia” wnosi nowe światło w rozumienie Bożego działania zbawczego w historii. Rozwinięcie tego wątku w odniesieniu do nowszej literatury zob. S. Zatwardnicki, Niepokalane Poczęcie. Czy łaska Odkupienia działa wstecz?, „Rocznik Teologii Katolickiej” 14 (2015) 2, s. 64-72. 
w dogmacie może być odebrane jako sugestia, że to właściwie już cała i jedyna interpretacja tajemnicy odkupienia. Takie jednak traktowanie formuły dogmatycznej byłoby niewłaściwe. Jej celem jest wypowiedzenie prawdy o Maryi, a nie definiowanie sposobu odkupienia przez nawiązanie do jednej szczególnej interpretacji. Mamy tu do czynienia z typowym problemem z zakresu interpretacji dogmatów. Definicja skoncentrowana jest na przedstawieniu nauki o niepokalanym poczęciu i ogłasza ją jako nieomylną naukę Kościoła. Posługuje się przy tym argumentacją teologiczną, przywołującą inną prawdę wiary, czyniąc to w koniecznym skrócie. Prawdą wiary jest nauka o odkupieniu, skróconą interpretację teologiczną przedstawia odwołanie się do kategorii zasługi. Nie da się z omawianego dogmatu wyciągać tezy, że nauka o zasłudze Chrystusa (a właściwie tutaj samo pojęcie zasługi bez szerszego kontekstu) stanowi pełną wykładnię wiary Kościoła o odkupieniu.

\section{Wniebowzięta}

Najnowszy dogmat maryjny okazał się przede wszystkim ważnym punktem odniesienia dla debat antropologicznych na temat tożsamości cielesno-duchowej człowieka w stanie eschatologicznym. Także z punktu widzenia naszego tematu rysuje się pewna znacząca perspektywa myślowa, chociaż nie jest ona wprost związana ze specyfiką tej definicji dogmatycznej, lecz dotyczy jej szerszego horyzontu treściowego. Chodzi mianowicie o samo podstawowe stwierdzenie faktu, że życie człowieka nie zamyka się w doczesności, lecz jest skierowane ku wieczności w Bogu i w niej uzyskuje spełnienie. Ten artykuł wiary ma charakter stricte soteriologiczny. Historia zbawienia zmierza do eschatologicznego spełnienia, czyli wiecznego życia zbawionych przed Bogiem - w relacji z Bogiem. Podobnie trzeba powiedzieć o pojedynczym człowieku. Historia zbawienia osoby ludzkiej zaczyna 
się w doczesności, ale swoje spełnienie, czyli zbawienie, człowiek uzyskuje dopiero w wieczności, czyli po życiu doczesnym.

To przypomnienie może się wydać na swój sposób banalne. Warto jednak najpierw zwrócić uwagę, że taka też była jedna $z$ intencji papieża Piusa XII, ogłaszającego dogmat o wniebowzięciu krótko po katastrofalnych doświadczeniach drugiej wojny światowej: chodziło mu o przywołanie nadziei chrześcijańskiej na niebo, czyli na ostateczny triumf Boga nad złem i na szczęśliwe życie każdego człowieka. Maryja uroczyście czczona jako wniebowzięta może taką nadzieję wzmacniać8.

Dla teologii to samo przypomnienie okazuje się równie ważne z innych względów. Sytuacja współczesnej teologii jest pod tym względem specyficzna. Przez wieki mogła rozwijać się silna eschatologizacja wiary, duszpasterstwa, teologii. Zgadzało się to z doświadczeniem życia jako krótkiego, zagrożonego i przebiegającego w różnych konkretnych niedolach. Pojawiającemu się w takich okolicznościach umniejszaniu znaczenia doczesności jako miejsca przeżywania szczęścia towarzyszyły jednak idee zdecydowanie krytyczne wobec tego typu jednostronności. Można w dużym skrócie, a jednak trafnie powiedzieć, że na takiej narastającej krytyce zaczęła się budować od odrodzenia przez oświecenie i kolejne epoki nowoczesna, wolnościowa i techniczna cywilizacja europejska (a dziś należałoby powiedzieć: światowa). Mimo często wskazywanych ambiwalencji świętuje ona swój sukces. Odejście od zanurzenia w eschata i koncentracja na przemienianiu znanego nam świata przyniosła niezwykły postęp, poprawę warunków życia ludzkości w bardzo wielu obszarach. Rozwinęły się ruchy wyzwoleńcze ludów, rozszerzyły prawa samostanowienia dla grup i jednostek, reformują się sys-

8 Myśl zawarta w pierwszych słowach Konstytucji Munificentissimus Deus i powtórzona pod koniec. Sama zaś formuła dogmatyczna we wprowadzeniu podkreśla, że dogmat zostaje ogłoszony nie tylko ku chwale Boga i dla „powiększenia chwały dostojnej Matki”, ale też „dla radości i wesela całego Kościoła”. 
temy społeczne, w niebywały sposób rozwinęła się technika. Można rozwijać długą listę osiągnięć cywilizacji, która uwierzyła w możliwość skutecznej poprawy świata i losu żyjących w nim ludzi. Złe skutki tych procesów bądź zjawiska patologiczne samego rozwoju są traktowane jako wyzwanie do zaangażowania, a nie źródło fatalistycznego myślenia i rezygnacji. Na styku z religią ten optymizm cywilizacyjny łatwo nabierał (i wciąż nabiera) rysów konfliktu z religią, która - zgodnie $\mathrm{z}$ nietzscheańskim zarzutem i jego licznymi odmianami, a wśród nich z nowoczesną wersją "nowego ateizmu” Dawkinsa - jakoby odbiera smak życia. Niepotrzebność tego konfliktu starał się odsłonić II Sobór Watykański, zwracając uwagę na ewangeliczny nakaz rozwoju świata i na uznanie autonomii spraw „ziemskich”. W nowszej teologii wydarzyło się bardzo wiele w zakresie opracowania wartości tychże spraw doczesnych człowieka. A jednak pozostało zasadnicze pytanie o kształt relacji między tym światem „przedostatnim" a rzeczywistością ostateczną. Ostrość tego pytania widać także w teologicznym myśleniu o odkupieniu. Wiele poczyniono we współczesnej teologii starań, by wskazać na doczesne wymiary dzieła odkupienia. Koncepcje takie stają jednak w kluczowym momencie na powrót przed pytaniami, czy wciąż pozwalają rozumieć, że pełnia zbawienia jest w wiecznej wspólnocie z Bogiem i jak należy ujmować relację między tym, co ostateczne, a tym, co "przedostatnie”.

Trzeba stwierdzić, że soteriologia, która nie radzi sobie z perspektywą eschatologiczną, czyli taka, dla której jest ona nieważna bądź nie mieści się w logice jej wyjaśnień, jest soteriologią nie tylko potrzebującą uzupełnień, ale wręcz może być po prostu nieprawidłową koncepcją. Na podstawie wyżej przedstawionych racji nie da się odpowiedzialnie mówić o zbawieniu człowieka, jeśli nie uwzględni się perspektywy wieczności w Bogu. Stąd trzeba uznać, że dogmat o wniebowzięciu, przypominając o per-

9 Por. KDK 33-39. 
spektywie ostatecznej ludzi i świata, oddaje wielką przysługę teologii odkupienia. Przywołuje wątek wiary, bez którego nauka o odkupieniu ostatecznie nie miałaby sensu.

\section{Podsumowanie}

Najłatwiej podsumować niniejszą krótką refleksję nad teologiczną wrażliwością maryjną stwierdzeniem, że odświeża ona pamięć o podstawowych prawdach wiary. Tym samym przypomina także o ważnym zakotwiczeniu teologii odkupienia w tychże prawdach. U podstaw tej konstatacji leży inne stwierdzenie: w maryjnej doktrynie wyłożonej w obrębie czterech dogmatów można zaakcentować wielorakie powiązania $\mathrm{z}$ całością treści wiary, a tym samym z całością teologii. Maryjna teologia odeszła daleko od stanu izolacji od innych treści wiary - stanu, który diagnozowano w nieodległej przeszłości. Starałem się wskazać, że przynajmniej niektóre elementy wrażliwości maryjnej teologa - nawet jeśli upominają się o sprawy oczywiste - mają dzisiaj dla teologii odkupienia pierwszorzędne znaczenie.

Nie można zapomnieć o przyczynie tego faktu, o tym, że mariologia wiedzie do podstawowych treści wiary. Jest bowiem teologią w konkrecie. O ile teologia zawsze mówi o Bogu w relacji do świata (nawet gdy mówi o Nim in se), a zwłaszcza wiele miejsca poświęca relacji „Bóg - człowiek”, o tyle teologiczna nauka o Maryi jest zawsze szczególnym przypadkiem tej całościowej refleksji. Ponieważ zaś mariologia skonstruowana jest szczególnie uważnie od strony doktrynalnej, toteż uważnie odsyła do całej teologii i tym samym wciąż o niej przypomina.

Mariologia ancilla soteriologiae? Tak, nawet: Mariologia ancilla theologiae. Wypada uznać, że określenie takie dobrze wpisuje się w specyfikę wrażliwości maryjnej. 


\section{„Marianische Sensibilität" und die Theologie der Erlösung}

Der Text bietet sich als eine einführende Reflexion über die $\mathrm{Zu}$ sammenhänge zwischen einer „marianischen Sensibilität des Theologen" und der Soteriologie (im engeren Sinne als Auslegung der Heilsbedeutung des Christusereignisses verstanden). Die Reflexion ist rund um 4 marianische Dogmen konzentriert. Es wird auf einige sich deutlich abzeichnende Themen der Soteriologie hingewiesen, die durch die „marianische Sensibilität“ hervorgehoben werden. Als besonders charakteristisch zeigen sich in diesem Licht einige bekannte neuzeitliche Herausforderungen der Theologie. Es handelt sich vor allem um das Verstehen des Verhältnisses „Freiheit - Gnade“ im Sinne der Formel „Freiheit als Gnade" und um das Heilsverständnis im Spannungsfeld von Geschichte und Eschaton. 